\title{
A CATALOGUE OF SEMATOPHYLLACEAE TYPES DEPOSITED AT BRYOLOGICAL HERBARIUM OF THE KOMAROV BOTANICAL INSTITUTE IN ST. PETERSBURG, RUSSIA
}

\author{
КАТАЛОГ ТИПОВЫХ ОБРАЗЦОВ СЕМ. SЕМАТОРНYLLACЕАЕ \\ В БРИОЛОГИЧЕСКОМ ГЕРБАРИИ БОТАНИЧЕСКОГО ИНСТИТУТА \\ ИМ. В.Л. КОМАРОВА В САНКТ-ПЕТЕРБУРГЕ, РОССИЯ \\ Paulo E.A.S. CÂMARA ${ }^{1}$, LJubov E. Kurbatova², Olga M. AfOninA², \\ DENISE P. COSTA ${ }^{3} \&$ MICHELINE CARVALHO-SILVA $^{1}$
ПАУЛО Е.А.С. КАМАРА ${ }^{1}$, ЛЮБОВЬ Е. КУРБАТОВА ${ }^{2}$, ОЛЬГА М. АФОНИНА ${ }^{2}$, ДЕНИЗЕ П. КОСТА ${ }^{3}$, МИШЕЛИНЕ КАРВАЛО-СИЛВА ${ }^{1}$

Abstract

Types are a fundamental part of good taxonomy practices. We were able to locate 38 types from the family Sematophyllaceae deposited at the Bryological Herbarium of Komarov Botanical Institute in St. Petersburg; from these, 25 are isotypes, 18 syntypes and 2 isolectotypes.

Резюме

В бриологическом гербарии Ботанического института им. В.Л. Комарова хранится одна из богатейших коллекций мхов, включающая около 300000 образцов; коллекция типов включает примерно 450 таксонов. В настоящей статье представлены результаты проведенного исследования, связанного с поиском типового материала, имеющего отношение к сем. Sematophyllaceae. Было обнаружено 38 типовых образцов, включающих 25 изотипа, 18 синтипа и 2 изолектотипа.

KEYWORDS: bryophytes, mosses, types, Sematophyllaceae, Herbarium of Komarov Botanical Institute

\section{INTRODUCTION}

Good taxonomic practice relies largely on the correct application of plant binomial names, which depends largely on the correct identification and study of type materials. Unfortunately it is not always an easy task to find them, as they are mostly comprised of old collections, sometimes badly preserved (or even lost), and frequently found scattered across many herbaria (Câmara et al., 2014a). Another problem is the lack of a comprehensive worldwide catalog of types of plant taxa. Many of the type specimens are not identified as such, and to correctly locate them often will need big effort and an exhaustive search across the herbarium collections and literature (Câmara et al., 2014a, b).

Sematophyllaceae is mostly a pantropical moss family, from which so far only one species has been cited for Russia (Ignatova et al., 2009). The family is one of the largest among the pleurocarps and is considered as one of the most difficult one (Buck \& Tan, 1989) and avoided by most taxonomists.

Following the molecular data published by Tsubota (2001a, b), the family has been shown to comprise two main clades. Goffinet \& Buck (2004) described the new family Pylaisiadelphaceae to accommodate one of the clades. For practical reasons in this paper we consider Sematophyllaceae sensu lato (Sematophyllaceae + Pylaisdelphaceae).

The Bryophyte Herbarium at the Komarov Botanical Institute (LE) in St.-Petersburg is one of the largest in Russia. Its total holdings are more than 300000 specimens. The foundation and the history of the herbarium are connected with the Russian Academy of Sciences since 1725. The first and early collections were made by J.Ch. Buxbaum (vicinity of St.-Petersburg and Astrakhan), I.G. Gmelin, G.W. Steller and J.P. Falck (Siberia), P.S. Pallas (the Crimea), J.G. Georgi and St.P. Kraszeninnikow (vicinity of St.-Petersburg), J.A. Güldenstädt (the Caucasus) and others. In the bryological herbarium of Komarov Botanical Institute are also kept collections identified by famous foreign bryologists - e.g., V.F. Brotherus, S.O. Lindberg, H.W. Arnell, E.A.F. Russow, K.J.A. Müller, and also numerous collections gathered by participants of the expeditions organized by the Russian Academy of Sciences for the thorough scientific exploration of Rus-

\footnotetext{
1 - Universidade de Brasilia, Depto. de Botanica, Campus Darcy Ribeiro, Asa Norte, 70910-900, Brasilia, DF, Brazil. e-mails: paducamara@gmail.com; silvamicheline@gmail.com

2 - V. L. Komarov Botanical Institute Rus. Acad. Sci., Prof. Popov Str., 2, St. Petersburg, 197376 Russia; e-mails: stereodon@yandex.ru, korablik-1@mail.ru

3 - (Instituto de Pesquisas Jardim Botanico do Rio de Janeiro. Rua Pacheco Leao 915, 22460-030, Rio de Janeiro, RJ, Brazil. email: denisepinheirodacosta@gmail.com
} 
sia. These specimens were collected mainly by famous Russian botanists, such as, G.G. Borszczow, I.N. Gorozhankin, S.G. Navashin, A.A. Elenkin, A.A. Sapegin, R.R. Pole, V.L. Komarov and others. Recent collections of bryophytes from different regions of Russia have been also made by L.I. Savicz-Lubitzkaja, K.I. Ladyzhenskaja, Z.N. Smirnova, A.L. Abramova, I.I. Abramov, A.L. Zhukova. Due to its historical significance of this collection, many important bryologists from 1800th and 1900th (i.e., V.F. Brotherus, Müller Hallensis) usually sent duplicates there. Some specimens (like Müller Hallensis's collections) were eventually destroyed during World War II (Merril, 1943; Hiepko, 1990) and they are likely to exist only there.

At present the Herbarium of bryophytes is a part of the Laboratory of Lichenology and Bryology of Komarov Botanical Institute. In past decades the Herbarium has enriched its holding by receiving numerous collections of mosses and liverworts recently gathered in different regions of Russia: Arctic and Siberia (O.M. Afonina, I.V. Czernyadjeva, A.D. Potemkin), Russian Far East (O.M. Afonina, I.V. Czernyadjeva, E.Yu. Kuzmina), Caucasus (G.Ya. Ukrainskaya), European Russia (L.A. Volkova, G.V. Vjunova, E.O. Kuzmina, A.D. Potemkin, L.E. Kurbatova,). From the Soviet period to the present time there is an active exchange of mosses and liverworts collections with leading foreign and domestic herbaria.

Collection of bryophyte type specimens comprises about 450 taxa at LE Herbarium. Identification and selection of type samples was started in the 60s of the last century. Usually this kind of work was carried out in conjunction with the revision of some taxonomic groups of bryophytes. In this paper we list the type materials of Sematophyllaceae found during a short visit to LE. We acknowledge the possibility of the existence of more Sematophyllaceae type materials kept at Komarov Botanical Institute beyond the ones listed here, so more visits may be necessary.

\section{MATERIAL AND METHODS}

A recent visit to the LE herbarium has allowed me to investigate about 1000 specimens of the family Sematophyllaceae. The TROPICOS database (www.tropicos.org) and the Biodiversity Heritage Library (www.biodiversity library.com) were consulted for checking the literature for types. Also the papers by Sayre (1977) and Thiers (1992) were consulted. This is not a monographic or taxonomic revision, so we do not provide any new lectotypifications, combinations or synonymizations (however, when synonymizations were already done, we provide the references). Also, when needed, some taxonomic notes are provided. Results are presented first in alphabetical order of the basionym, and the deriving combinations are presented in chronological order. We also present data on the locations of other type duplicates (when known). The sign "!" means that the voucher at LE was studied. However, when it was not possible to study the type, but its location is certain (much information is available on line these days) we mention the acronym of the hosting herbarium without the "!". Collector's names are presented in italics. Vouchers were also studied under light microscope to verify its correct identity and photographed, then, all studied material was put back into its original specimen envelopes. When useful information was not present in the protologue but elsewhere in the publication, it is presented in brackets ([ ]). Information from the protologue and from labels is provided separately. Both are copied as they were found in the original sources (sic erat scritum). Some of the old literature is often vague and usually lacks important information for assigning the specimens as types, a challenging situation quite common in plant taxonomy.

\section{RESULTS}

A total of 25 isotypes, 17 syntypes, and 2 isolectotypes were found at LE for 38 names of Sematophyllaceae. Also five are Müller Hallensis's names. This is of a high importance because the original herbarium of Carl Müller of Halle in Berlin was destroyed during WWII (Merrill, 1943). The type materials at Komarov Botanical Institute may provide good specimens for the taxon lectotypification. Finally, several original materials of invalid names were also found and are presented at the end.

\section{LIST OF TYPES OF SEMATOPHYLLACEAE IN LE.}

1. Acanthodium rigidum Mitt., J. Linn. Soc., Bot. 10: 182. 1868. - Sematophyllum rigidum (Mitt.) Mitt., F1. Vit. 398. 1873. - Acanthocladium rigidum (Mitt.) Broth., Monsunia 1: 51. 1899. - Trismegistia rigida (Mitt.) Broth., Nat. Pflanzenfam. I (3): 1078. 1908. Trismegistia calderensis var. rigida (Mitt.) H. Akiy., Humans and Nature 21: 11. 2010, nom. invalid. [illegitimate basionym]

Protologue: [Samoa]. Tutuila, on trees and rocks in gullies on the sides of the mountains (1200-1500 ft.) No 55. [Powell].

Label: Samoa, $170^{\circ}$ Long. W. $14^{\circ}$ Lat. S. Rev. T. Powell no 55 (holotype: NY, isotype: LE!). Comments: According to Thiers (1992), the holotype is in NY, but we were not able to see it during our visit there.

2. Leskea homomalla Hampe, Icon. Musc. 6. 1844. - Hypnum homomallum (Hampe) Müll. Hal., Syn. Musc. Frond. 2: 336. 1851. - Pylaisia homomalla (Hampe) A. Jaeger, Gen. Sp. Musc. 2: 373. 1878. - Rhaphidorrhynchum homomallum (Hampe) Mitt., Trans. Roy. Soc. Victoria 19: 84. 1883, comb. invalid. [The genus was never described] - Rhaphidostegium homomallum (Hampe) Broth., Nat. Pflanzenfam. I (3): 1114. 789. 1908. - Sematophyllum homomallum (Hampe) Broth., Nat. Pflanzenfam. Ed. 2 11: 433. 738. 1925.

Protologue: ad corticem Banksia Menziessi Novae Hollandiae, prope Oppidulum Perth. Legit Dr. L. Preiss. 19. Aug. 1839.

Label: Nova Hollandia, leg Preiss 2465 (holotype: BM; 
isotypes: LE!, MO, NY!). Comments: The holotype is in BM (available online), but we were not able to see it during our visit there. The original protologue does not mention the collection number (2465), but as far as we could investigate there is no other specimen that matches the protologue. The specimens at BM, MO and NY all contain such collection number and are all labeled as types.

3. Hypnum afroacuminulatum Müll. Hal., Bot. Jahr. Syst. 5: 88. 1884. - Taxithelium afroacuminulatum (Mu?1l. Hal.) Paris, Index Bryol. 1260. 1898.

Protologue: [Dier auf der Expedition S.M.S. Gazelle von Naumann] Mungo.

Label: Mungo. Gazelle Expedition. Naumann, 1874. n. sp. (isotypes: BM!, E!, FH!, LE!). [= Taxithelium planum Mitt. (Câmara 2011)]. Comments: Mungo is located in nowadays Cameroon. Even lacking collecting number, all other label data and protologue data match; also the year of collection, 1874 , precedes the publication year (1884), a worth noting information. TROPICOS cited the year of publication as 1883 but the correct one is 1884. The label annotation " $n . s p$." indicates that the author consider it as a new species.

4. Hypnum austropulchellum Müll. Hal., Bot. Jahrb. Syst. 5: 82. 1883. — Plagiothecium austropulchellum (Müll. Hal.) Kindb., Enum. Bryin. Exot., suppl. 2, 102. 1891. - Isopterygium austropulchellum (Müll. Hal.) Broth., Nat. Pflanzenfam. I (3): 1081. 1908.

Protologue: [Dier auf der Expedition S.M.S. Gazelle von Naumann] Kerguelen.

Label: Kerguelen, Gazelle Expedition. Naumann 1874. n.sp. (isotype: LE!). Comments: Even lacking collecting number, all other data label and protologue data match, also the collecting year, 1874, which precedes the publication year (1884) is worth noting. TROPICOS cited the year of publication as 1883 , but the correct one is 1884 .

5. Hypnum bruchii Dozy \& Molk., Ann. Sci. Nat. Bot. sér. 3. 2: 306. 1844. — Sematophyllum bruchii (Dozy \& Molk.) A. Jaeger, Gen. Sp. Musc. 2: 446. 1878. Trichosteleum bruchii (Dozy \& Molk.) Broth., Nat. Pflanzenfam. I (3): 1119. 1908. — Rhaphidostichum bruchii (Dozy \& Molk.) M. Fleisch., Musci Buitenzorg 4:1312. 1923. - Papillidiopsis bruchii (Dozy \& Molk.) W.R. Buck \& B.C. Tan, Acta Bryol. Asiat. 1: 12. 1989.

Protologue: [In the introduction of this paper (Musci Frondosi ex Archipelago Indico et Japonia) it is said that the collections from Sumatra were made by either Blume, Kuhl et Van Hasselt, Zippelio, Korthals or Forten]. Sumatra.

Label: Sumatra, Korthals (isotypes: LE!, NY!). Comments: As Dozy and Molkenboer's herbaria are located in the Netherlands, types for this name was expected to be found at L or U, but according to Câmara et al. (2014) there are none in either. Also as is often the case with very old references there is always some relevant data missing, but this specimen at LE is, to the best of our knowledge, a duplicate of the type.

6. Hypnum chlorosum Hampe, Flora 64: 414. 1881. - Isopterygium chlorosum (Hampe) Paris, Index Bryol. 706. 1897.

Protologue: [Brazil]. Prope Rio de Janeiro, Glaziou (11733).

Label: Brasilia, A. Glaziou 11733 (types: BM!, LE!, $\mathrm{PC}$ !; in LE is isotype; leptotypification is discussed by Costa et al. 2016, submitted to Taxon, in press) ${ }^{1}$.

7. Hypnum nepalense Schwägr., Sp. Musc. Frond., suppl. 3, 1 (2): 226. 1828. — Stereodon nepalensis (Schwägr.) Mitt., J. Proc. Linn. Soc., Bot., Suppl. 2: 100. 1859. - Trichosteleum nepalense (Schwägr.) A. Jaeger, Gen. Sp. Musc. 2. 1878. - Taxithelium nepalense (Schwägr.) Broth., Monsunia 1: 51. 1899.

Protologue: In regno Nepal, ad terra lectum dedit $\mathrm{Pr}$. Hooker.

Label: Nepal, Hooker (holotype: G!, isotypes: BM!, G!, LE!). Comments: As is often the case with old literature, both the protologue and label are quite vague, but they do match. We consider this very likely to be an isotype.

8. Hypnum pulvinale Hampe, Vidensk. Meddel. Dansk Naturhist. Foren. Kjřbenhavn. Ser 3, 10: 271. 1878. - Rhaphidostegium pulvinale (Hampe) A. Jaeger, Gen. Sp. Musc. 2: 775. 1880. - Sematophyllum pulvinale (Hampe) W.R. Buck, Nova Hedwigia 66: 242. 1998.

Protologue: [Brazil, vicinias urbis Rio de Janeiro, lecti Dr. A. Glaziou] in terra sub 7450.

Label: Brasilia, A. Glaziou n. 7450 (types: BM!, LE!, $\mathrm{PC}$ !; in LE is isotype; leptotypification is discussed by Costa et al. 2016, submitted to Taxon, in press) ${ }^{1}$.

9. Hypnum pseudotanytrichum Dozy \& Molk., Bryol. Jav. 2: 150. 248. 1866. - Sematophyllum pseudotanytrichum (Dozy \& Molk.) Paris, Index Bryol. Suppl. 307. 1900. - Acanthocladium pseudotanytrichum (Dozy \& Molk.) Broth., Index Bryol., ed. 2, 1: 2.1903.

Protologue: [Indonesia] Habitat insulam Javae; in $\mathrm{m}$. Gedé. Van Gesker; in sylvis supreme m. Mandalawangi m. Apr. c. fructu, Junghuhn. —Label: Java, Junghuhn (syntype: LE!). Comments: According to Câmara et al. (2014), no type material for this name was found at the Netherlands Herbaria (L or U), the house of Dozy \& Molkenboer's collections. The syntype, Van Gesker s.n., was also not found at LE.

10. Hypnum restitutum Hampe, Vidensk. Meddel. Dansk Naturhist. Foren. Kjřbenhavn. ser. 4, 1: 141. 1879. - Isopterygium restitutum (Hampe) Kindb., Enum. Bryin. Exot., suppl. 2, 100. 1891. - Sematophyllum restitutum (Hampe) Paris, Index Bryol. 1169. 1898.

Protologue: [Brazil]. In vicinia Rio de Janeiro sub Nr. 7163 et 7455 intermixtum parce legit Glaziou.

Label: Brasilia, A. Glaziou 7455 (syntypes: BM!, PC,

1 - Preliminary reference: Costa, D.P., Peralta, D.F., CarvalhoSilva, M. \& Camara, P.E.A.S. [2016]. Types of moss names introduced by Ernst Hampe based on Glaziou's collections from Brazil. - Taxon. 
LE!). Comments: The syntype, Glaziou 7163, was not found at LE.

11. Hypnum sphaerotheca Müll. Hal., Syn. Musc. Frond. 2: 333. 1851. — Rhaphidostegium sphaerotheca (Müll. Hal.) A. Jaeger, Gen. Sp. Musc. 2: 458. 1878. Rhynchostegium sphaerotheca (Müll. Hal.) Dixon \& A. Gepp, Bull. Misc. Inform. Kew. 1923: 216. 1923. - Sematophyllum caespitosum fo. sphaerotheca (Müll. Hal.) P. de la Varde, Mém. Soc. Sci. Nat. Math. Cherbourg. 1: 210. 1936. - Sematophyllum sphaerotheca (Müll. Hal.) P. de la Varde, Arch. Bot. (Forlě) 1(3): 121. 1938. Invalid.

Protologue: [South Africa] Prom. B. spei: Pappe, Zeyher; ad cataractam $\mathrm{m}$. tabularis et inter saxa ad cataractuam m. diabolic orientalis, 12 Sept. 1824: Ecklon; ad Hangklipp primi leg. Mundt et Maire 1821.

Label: Prom. Bonae Spei leg. Ecklon s.n. (syntype: LE!).

12. Hypnum tanytrichum Mont., Ann. Sci. Nat., Bot., sér. 3, 4: 88. 1845. - Stereodon tanytrichus (Mont.) Mitt., J. Proc. Linn. Soc., Bot., Suppl. 2, 112: 157. 1859. — Hylocomium tanytrichum (Mont.) A. Jaeger, Gen. Sp. Musc. 2: 616. 1880. - Sematophyllum tanytrichum (Mont.) Paris, Index Bryol., Suppl. 308. 1900. — Acanthocladium tanytrichum (Mont.) Broth., Index Bryol., ed. 2, 1: 3. 1903. - Wijkia tanytricha (Mont.) H.A. Crum, Bryologist 74: 174. 1971.

Protologue: [Indonesia]. Hab. Java insula cum Leskea straminea. Herb. Webb. Zolling. Coll. № 1737.

Label: Patria Javanica a cl. Zollingero lecta. No 1737 (holotype: PC, isotype: LE!). Comments: The holotype is in PC (available online), but we were not able to see it during our visit there.

13. Hypnum tequendamense Hampe, Linnaea 31: 529. 1862. - Sematophyllum tequendamense (Hampe) Mitt., J. Linn. Soc., Bot. 12: 491. 1869. — Rhaphidostegium tequendamense (Hampe) A. Jaeger, Gen. Sp. Musc. 2: 749.1878.

Protologue: [the title of the original paper is Species novas muscorum ad Dr. Alexandre Lindigio in NovaGranada mensibus Julio et Augusto a 1861 collectus] Nova-Granada, Tequendama ad arbores, alt. 2500 metr. Aug. 1861, sub no 2153.

Label: Nova Granada, n. 2153. Lindig. (holotype: BM!, isotypes: LE!, NY!).

14. Hypnum trachyamphorum Müll. Hal., Bot. Jahrb. Syst. 5: 85. 1883. - Trichosteleum trachyamphorum (Müll. Hal.) Kindb., Enum. Bryin. Exot., suppl. 2, 104. 1891.

Protologue: [original paper is entitled Die auf der Expedition S.M.S. Gazelle von Dr. Naumann gesammelten Laubmoose]. Nova Hannovera et insula Anachoretes.

Label: Nova Hannovera, Gazelle Expedition, D. Naumann. (isotype: LE!).

15. Isopterygium andamanicum Gangulee, Mosses E. India 8: 1953. f. 1002. 1980.

Protologue: Typus lectus a E.H. Man in Andamania (Port Blair), anni 1893, et positus in Bryotheca E. Levier in BM sub numero 2477.
Label: Bryotheca E. Levier, in insula Andaman merid. Port Blair, 1893, legit E.H. Man determ. C. Mueller sub no 2477 (holotype: BM, isotype: LE!). Comments: the holotype is at BM, unfortunately we were not able to study it during our visit to BM (possible was on loan), but the curators later provided a picture of the specimen (and its label) confirming it is housed there. Concerning the number 2477, it is believed that it is not the collecting number, but a Bryotheca Levier's number. This can be inferred both by the protologue as well as from the labels. The number 2477 was never associated with the collector's name, but with the collection's name. In the label, there is a space for the collector's number after a coma, but it is empty (there is no number after Man's name). So we are considering the voucher as Man s.n. (and 2477 as an herbarium number). There are also some specimens housed in Paris (PC) that match the name, collector and collecting year, but differ from the Bryotheca Levier's number, so we are not considering them as types. Also the presence of "nov. sp." on the label indicates that the author intended it to be a new species.

16. Isopterygium affusum Mitt. J. Linn. Soc., Bot. 12: 499. 1869.

Protologue: Hab. Fl. Negro, ad rupes cataractae riv. Tarumá irroratas, inter Selaginellas, Spruce, n. 1059; Brasilia, Sierra de Araripe, prov. Ceara, Gardner, n. 106 c.

Label: SPRUCE. Musci Amazonici et Andini. No. 1059. (isotype: LE!).

17. Macrohymenium laeve Thwaites \& Mitt., J. Linn. Soc., Bot. 13: 317. 1873. - Regmatodon laevis (Thwaites \& Mitt.) Paris, Index Bryol. 1109. 1898.

Protologue: Hab. Ins. Ceylon, Dr. Thwaites.

Label: C.M. Central Province, Ceylon Thwaites (holotype: NY!; isotype: LE!). Comments: The original protologue does not cite any number, however, Thiers (1992) considered the type as Thwaites 236. The label at L also presents the same number (236) but not clearly associated with the collector.

18. Meiothecium negrense Spruce ex Mitt., J. Linn. Soc., Bot. 12: 471. 1869. - Pterogoniella negrensis (Spruce ex Mitt.) A. Jaeger ex Paris, Index Bryol. 1047. 1898. - Sematophyllum negrense (Spruce ex Mitt.) W.R. Buck, Contr. Univ. Michigan Herb. 15: 139. 1982.

Protologue: Hab. Fl. Negro, S. Carlos in Artocarpi incisae radicibus, Spruce n. 969; Uanauaca, ad arborum radices, Spruce n. 970. Andes Peruviaae, Tarapoto, Spruce. Andres Quitenses, Jameson.

Label: SPRUCE, Musci Amazonici et Andini. No 970 (lectotype, designated by Florschuetz-de-Waard (1992) NY!, isolectotypes: LE!, NY!). [= Potamium deceptivum Mitt. (Florschuetz-de-Waard, 1992)].

19. Meiothecium bogoriense M. Fleisch., Musci Buitenzorg 4: 1228. 201 f. 1-3. 1923.

Protologue: Exs. M Fleischer, M. Archipel. Ind. No 240 (1902).

Label: Musci Frond. Archipelagi Indici. 240. 1902. 
West Java: In Buitenzorg and Alleebaumen im botanischen Garten und Umgebund 270m (isotype: LE!). Comments: The label states it as $n$. sp. (New Species). Comments: The protologue and label match but is not clear who is the collector as only the exsicatae information is mentioned.

20. Meiothecium scabriusculum var. patens Besch., Ann. Sci. Nat., Bot., sér. 6, 3: 226. 1876. - Pterogoniella patens (Besch.) Schimp. ex Paris, Index Bryol. 1048. 1898.

Protologue: Martinique, sur les arbres, camp Balata, 450m altit. (HUSNOT, exsicc., $\mathrm{n}^{\circ}$ 172).

Label: Husnot. pl. des Antilles- 1868, 172. Les Camps Balata. Alt. 450m (holotype: BM, isotype: LE!). Comments: The holotype is in BM (available online), but we were not able to see it during our visit there.

21. Plagiothecium flaviusculum Müll. Hal., Hedwigia 40: 59. 1901. - Isopterygium flaviusculum (Müll. Hal.) Broth., Nat. Pflanzenfam. I (3): 1082. 1908.

Protologue: Brasilia, Rio de Janeiro, Restinga de Mauá, in sylva palustri, Aug. 1897: E. Ule, Coll. No 1941.

Label: E. Ule. Bryotheca Brasiliensis 234. Rio de Janeiro, Mauá, in silva solo paludoso, Aug. 1897. Leg. E. Ule. (isotypes: BM, JE, LE!, MO!, NY, PC ). Comments: Ernst Ule's collections frequently have two numbers associated, one is his collecting number and another one is his Bryotheca Brasiliensis number, in this case, only his Bryotheca number is present. The expression " $n$. sp." is also printed on the label indicates the original intention of it being a new species. The specimens at BM, JE, MO, NY and PC are all available online, have all been annotated as types and contains exactly the same label and numbers as the one in LE.

22. Plagiothecium villae-ricae Besch., Mém. Soc. Sci. Nat. Math. Cherbourg 21: 271. 1877.

Protologue: [Note sur les Mousses du Paraguay. Recoletés par M. Balansa]. Villa-Rica 1210.

Label: Paraguay, Guairá, Villa Rica, Balansa 1210. [= Isopterygium tenerifolium Mitt. (Buck \& Ireland, 1989)]. Comments: According to Buck \& Ireland (1989) the holotype is at BM and isotype in NY, but we were not able to see it during our visit to those herbaria.

23. Pterogoniella diversifolia Renauld \& Cardot, Bull. Soc. Roy. Bot. Belgique 29 (1): 179. 1890. — Meiothecium diversifolium (Renauld \& Cardot) Broth., Nat. Pflanzenfam. I (3): 1103. 1908.

Protologue: Hab. Madagascar: Tamatave (comm. Rodriguez), Ste-Marie (Arbogast), ad cortices arborum.

Label: Musci Mascareno-Madagascarienses. Sta. Marie de Madagascar. Leg. Rev. Arbogast (syntype: LE!). Comments: the syntype from Tatamave was not found. It is written on the label " $n$. $s p$." indicating that the author intended it to be a new species.

24. Potamium deceptivum Mitt., J. Linn. Soc., Bot. 12: 473. 1869. - Pterogoniella deceptiva (Mitt.) A. Jaeger ex Paris, Index Bryol. 1046. 1898. - Colobodon- tium deceptivum (Mitt.) J. Florsch., Fl. Guianas, Ser. C, Bryoph. 2 (Musci IV): 353. 2011.

Protologue: Hab. Fl. Casiquiari, Spruce, n. 821, 825; fl. Negro; fl. Uaupes, in rupibus inundatis; ad Panuré, Spruce, n. 822; fl. Uaupes, secus ostia frequens in truncus inundates, Spruce, N. 823; San Carlos, in truncis inundates, Spruce, n. 824.

Label: SPRUCE. Musci Amazonici et Andini. No 824 (syntypes: BM!, LE!, NY!).

25. Potamium pacimoniense Spruce ex Mitt., J. Linn. Soc., Bot. 12: 474. 1869. - Pterogoniella pacimoniensis (Spruce ex Mitt.) A. Jaeger, Index Bryol. 1048. 1898. - Sematophyllum pacimoniense (Mitt.) J. Florsch., Trop. Bryol. 3: 96.1990 [1Dec].

Protologue: Hab. Fl. Negro, in truncis inundates ad S. Carlos, Spruce, n. 828; ad fl. Pacimoni necnon ad ejus tributarium Uaiauaca, in ramis inundates vulgare, Spruce, n. 829; S. Gabriel, in truncis inundates, Spruce, n. 830.

Label: SPRUCE. Musci Amazonici et Andini. No 829 (lectotype: NY! designated by Florschutz-de Waard (1992), isolectotypes: BM!, LE!, W!).

26. Rhaphidostegium perrevolutum Broth., Bot. Jahrb. Syst. 20: 206. 1894. - Sematophyllum perrevolutum (Broth.) Broth., Nat. Pflanzenfam., 11: 431.1925.

Protologue: [Uganda]. Bukoka, auf Bäumen (Stuhlmann n. 1604).

Label: Bukoka, Sthulmann 1604 (isotype: LE!).

27. Sematophyllum inundatum Mitt., J. Linn. Soc., Bot. 12: A494. 1869. - Hypnum inundatum (Mitt.) Müll. Hal., Linnaea 39: 466. 1875, nom. illeg. [later homonym]. Trichosteleum inundatum (Mitt.) A. Jaeger, Gen. Sp. Musc. 2: 485. 1878.

Protologue: Hab. Fl. Negro, ad fl. Casiquiari, Spruce, n. 921; Marabitanas, n. 922, secus ostia fl. Uaupés, in truncis inundates, n. 925, Uaiauáca ad radices praecipue Citri aurantiae, n. 926, in ripis inundates ad saxa, n. 927, ibidem terrestre, n. 928, S. Gabriel ad rupis inundates, n. 929, 930, in terra arenosa fl. Uaupés inundata, n. 931, S. Carlos in lignis, n. 905, S. Gabriel in lignis, n. 906.

Label: Rio Negro, leg. Spruce 925, 931 (syntypes: BM!, LE!, NY!-slide). Comments: The voucher at LE contains the two syntypes glued side by side on the same sheet.

28. Sematophyllum monostictum Thwaites \& Mitt., J. Linn. Soc., Bot. 13: 318. 1873. - Rhaphidostegium monostictum (Thwaites \& Mitt.) A. Jaeger, Gen. Sp. Musc. 2: 474. 1878. - Trichosteleum monostictum (Thwaites \& Mitt.) Broth., Rec. Bot. Surv. India 1 (12): 326. 1899.

Protologue: Insl. Ceylon, Dr. Thwaites.

Label: C.M. Central Province, Ceylon. Thwaites (holotype: NY!, isotype: LE!). Comments: The original protologue does not cite any number, however, Thiers (1992) considered the type as Thwaites 223. The label at L also presents the same number (223) but not clearly associated with the collector. 
29. Sematophyllum oblique-rostratum Mitt., J. Linn. Soc., Bot. 12: 490. 1869. — Rhaphidostegium obliquerostratum (Mitt.) A. Jaeger, Gen. Sp. Musc. 2: 472.1878. - Rhaphidorrhynchium oblique-rostratum (Mitt.) Broth., Nat. Pflanzenfam., ed. 2, 11: 428. 1925.

Protologue: Hab. Andes Quitenses, Chimborazo, Jameson; fl. Pastaza, secus ostia rivuli Verde dicti (4000 ped.), Spruce n. 1001; in monte Tunguragua, in lignis (7000 ped), Spruce, n. 1002; in sylva Canelos (4000 ped.), Spruce, n. 1003.

Label: SPRUCE. Musci Amazonici et Andini No. 1002 (syntype: NY!, LE!). Andes Quito, Spruce 1003 (syntype: NY!, LE!). Comments: There are two duplicates of Spruce 1003 at LE.

30. Sematophyllum ramulinum Thwaites \& Mitt., J. Linn. Soc., Bot. 13: 319. 1873. - Rhaphidostegium ramulinum (Thwaites \& Mitt.) A. Jaeger, Gen. Sp. Musc. 2: 473. 1878. - Trichosteleum ramulinum (Thwaites \& Mitt.) Broth., Nat. Pflanzenfam. I (3): 1119. 1908. — Rhaphidostichum ramulinum (Thwaites \& Mitt.) Broth., Natür. Pflanzenfam. 11: 435. 1925. - Papillidiopsis ramulina (Thwaites \& Mitt.) W.R. Buck \& B.C. Tan, Acta Bryolichenol. Asiat. 1: 13. 1989.

Protologue: Hab. Ins. Ceylon, Dr. Thwaites.

Label: C.M. Central Province, Ceylon, Thwaites (holotype: NY!, isotype: LE!) Comments: The original protologue does not cite any number, however, Thiers (1992) considered the type as Thwaites 244. The label at L also presents the same number (244) but not clearly associated with the collector.

31. Sematophyllum ruficaule Thwaites \& Mitt., J. Linn. Soc., Bot. 13: 319. 1873. - Rhaphidostegium ruficaule (Thwaites \& Mitt.) A. Jaeger, Gen. Sp. Musc. 2: 474. 1878. - Clastobryophilum ruficaule (Thwaites \& Mitt.) M. Fleisch., Nova Guinea 12(3): 121. 1914, nom. invalid. [The genus was properly described only in 1923]. - Clastobryella ruficaulis (Thwaites \& Mitt.) M. Fleisch., Musci Buitenzorg 4: 1199. 1923. - Acroporium ruficaule (Thwaites \& Mitt.) Dixon, Bull. Torrey Bot. Club. 51: 250. 1924. - Clastobryum ruficaule (Thwaites \& Mitt.) Tixier, Rev. Bryol. Lichénol. 43: 451. 1977. - Trichosteleum ruficaule (Thwaites \& Mitt.) B.C. Tan, J. Hattori Bot. Lab. 70: 101. 1991.

Protologue: Hab. Insl. Ceylon, Dr. Thwaites.

Label: C.M. Central Province, Ceylon, Thwaites (holotype: NY!; isotype: LE!). Comments: The original protologue does not cite any number, however, Thiers (1992) considered the type as Thwaites 226. The label at L also presents the same number (226) but not clearly associated with the collector.

32. Stereodon penicillatus Mitt., J. Proc. Linn. Soc., Bot., Suppl. 2: 112. 1859. — Eurhynchium penicillatum (Mitt.) A. Jaeger, Gen. Sp. Musc. 2: 412. 1878. - Hylocomium penicillatum (Mitt.) A. Jaeger, Gen. Sp. Musc. 2: 616. 1880. - Acanthocladium penicillatum (Mitt.) Broth., Nat. Pflanzenfam I (3): 1076. 1908. — Wijkia penicillata (Mitt.) H.A. Crum, Bryologist 74: 173. 1971.

Protologue: Hab. In Himalayae orient. Reg. temp., Sikkim, J.D. Hooker (No 778, 1035, 1040, 1074).

Label: Sikkim Himal. N. 1040 J.D.H. (syntype: NY!, LE!); Sikkim regions, coll. J.D.H. 1035 (syntype: NY!, LE!); Sikkim, Regio temp. Coll. J.D.H. 1074 (syntype: NY!, LE!). Comments: The abbreviation J.D.H stands for Joseph Dalton Hooker. There are two duplicates of J.H.D. 1040 in LE.

33. Stereodon russulus Mitt., J. Proc. Linn. Soc., Bot., Suppl. 1: 94. 1859. - Platygyrium russulum (Mitt.) A. Jaeger, Gen. Sp. Musc. 2: 342. 1878. - Clastobryum russulum (Mitt.) Broth., Hedwigia 50: 137. 1910. Gammiella russula (Mitt.) M. Fleisch., Nova Guinea 12 (2): 121. 1914.

Protologue: Hab. In Himalayae orient., ad Sikkim, et Nepal orient. Reg. temp., J.D. Hooker! (No 763, 767).

Label: Sikkim Regio Temp. Coll. J.D.H. 763 (syntype: LE!, NY). Comments: The abbreviation J.D.H stands for Joseph Dalton Hooker. The syntype, Hooker 767, was not found.

34. Stereodon tristiculus Mitt., J. Proc. Linn. Soc., Bot., Suppl. 2: 102. 1859. - Rhaphidostegium tristiculum (Mitt.) A. Jaeger, Gen. Sp. Musc. 2: 458. 1878. Sematophyllum tristiculum (Mitt.) M. Fleisch., Musci Buitenzorg. 4: 1262. 1923. - Sematophyllum subpinnatum fo. tristiculum (Mitt.) B.C. Tan \& Y. Jia, J. Hattori Bot. Lab. 86: 51. 1999.

Protologue: Hab. In Mont. Khasian. Reg. temp. J.D. Hooker et T. Thomson (No 1087). In Assam superior, Griffith ! In Ceylon, Gardner (No 1034).

Label: Herb. Ind. Or. Hook. fil. T. Thomson. Hab. Ceylon, Regio. Coll. Gardner 1034 (syntype: LE!, NY!). Comments: The syntype, Hooker \& Thomson 1087, was not found.

35. Syringothecium sprucei Mitt., J. Linn. Soc., Bot. 12: 497. 1869. - Isopterygium sprucei (Mitt.) W.R. Buck, Bryologist 92: 529. 1989.

Protologue: Hab. Andes Quitenses, in sylva Canelos (3000 ped.), Spruce n. 1517.

Label: Andes Quito, n. 1517, Spruce, in Sylva Canelos 3000 ped. (holotype: NY, isotypes: LE!, NY!).

36. Taxithelium novae-guineae Dixon, Farlowia 1: 39. 1943.

Protologue: New Guinea Britannica, Kanosia, on stilt roots of Rhizophora in swamp, 22 Feb. 1935; coll. C.E. Carr 11470.

Label: Nova Guinea Britannica, Kanosia, in paludosis, coriticicola, skiophila, ca. 0m. leg. .C.E. Carr (11470) II. 1935 (holotype: BM!, isotypes: BR!, CANB!, DUKE!, FH!, H!, JE!, L!, LE!, M!, MICH!, NICH!, PC!, S!, SING!, US!, W!). [= Taxithelium leptosigmatum (Müll. Hal ex Geh.) Paris (Câmara 2011)].

37. Trichosteleum kaernbachii Broth., Bot. Jahrb. Syst. 17: 480. 1893. - Taxithelium kaernbachii (Broth.) Broth., Nat. Pflanzenfam. I (3): 1091. 1908. 

bach).

Protologue: Nova Guinea, Gogolexpedition (L. Kaern-

Label: D. N. Guinea, L. Kaernbach. Gogolexpedition (isotypes: BM!, FH!, LE!). Comments: The annotation "n. sp." present in the label suggests that the author considered it as a new species.

\section{DOUBTFUL MATERIALS}

1. Hypnum propinquum Harv., Icon. P1. 1: pl. 24: f. 9. 1837. - Stereodon propinquus (Harv.) Mitt., J. Proc. Linn. Soc., Bot., Suppl. 1: 96. 1859. - Brotherella propinqua (Harv.) M. Fleisch., Musci Buitenzorg 4: 1245. 1923. - Pylaisiadelpha propinqua (Harv.) W.R. Buck, Yushania 1(2): 13. 1984.

Protologue: [Nepal, from Harvey].

Label: [Nepal] Hooker (1836) (holotype: BM, isotypes: E, LE!). Comments: The holotype should be at BM (not found), there is a possible isotype at E (available online). This is a particularly difficult situation, as the protologue contains virtually no description and only a very simple illustration (it needs to be double checked with data from Companion to the Botanical Magazine that seems to have never been published). The specimen at LE contains a year that would match, but instead of Harvey it says Hooker, however, the original paper illustration was based on collections that belonged to Harvey but not necessarily made by him; on the other hand, Hooker is known to have been collecting in Nepal. So there is a possibility that this would be an isotype.

2. Rhaphidostegium pseudobrachythecium Broth., Bot. Jahrb. Syst. 24: 276. 1897. - Hypnum pseudobrachythecium (Broth.) Paris, Index Bryol. 671. 1897. - Rhaphidorrhynchium pseudobrachythecium (Broth.) Broth., Nat. Pflanzenfam. (ed. 2) 11:426. 1925.

Protologue: Kamerun: auf faulendem Holz bei Ekundu N'dene (Dusén).

Label: Africa Occid. Caremunia, March 1892. P. Dusén (isotype: LE!). Comments: the year is compatible and the information on protologue matches the label, unfortunately the label does not cite more precisely the locality.

\section{ORIGINAL MATERIAL}

1. Isopterygium argyroleucon Renauld \& Cardot, Index Bryol. 705. 1897. Invalid name for not presenting a description.

2. Isopterygium constrictum Broth., Gard. Bull. Straits Settlem. 4: 33. 1926. Invalid name for not presenting a description.

3. Hypnum orthocarpon Hornsch. ex Müll. Hal., Syn. Musc. Frond. 2: 253. 1851. Invalid name for being a later homonym.
4. Trichosteleum wrayi Broth., Gard. Bull. Straits Settlem. 4: 38. 1926. Invalid name for being cited as synonym with no description.

\section{ACKNOWLEDGEMENTS}

The Brazilian author thanks CNPQ and FAP-DF for providing funds and support for this study as part of the REFLORA program. We thank also Dr. M. S. Ignatov for his support, useful suggestions and help in the execution of this work.

\section{LITERATURE CITED}

BUCK, W. R. \& B. C. TAN. 1989. The Asiatic genera of Sematophyllaceae associated with Trichosteleum. - Acta Bryolichenologica Asiatica 1: 5-19.

CÂMARA, P.E.A.S. 2011. A review of Taxithelium subgenus Taxithelium (Bryophyta, Pylaisiadelphaceae). - Systematic Botany 36(4): 824835.

CÂMARA, P.E.A.S., M. CARVALHO-SILVA, \& M. STECH. 2014a. A catalogue of Sematophyllaceae (Bryophyta) types deposited in Dutch herbaria. - Nova Hedwigia 99: 145-155.

CÂMARA, P. E. A. S., M. CARVALHO-SILVA, M. S. D. DA SILVA \& D.F. PERALTA. 2014b. A catalog of Bryophyta types deposited at the National Museum of Brazil. - Acta Botanica Brasilica 28(4): 539547.

FLORSCHUTZ-DE-WAARD, J. 1992. A revision of the genus Potamium (Musci: Sematophyllaceae). - Tropical Bryology 5: 109-121.

GOFFINET, B. \& W. R. BUCK. 2004. Systematics of the Bryophyta (mosses): from molecules to a revised classification. - In: Goffinet, B., V. Hollowell \& R. Magill (eds.). Molecular systematics of bryophytes. Monographs in Systematic Botany from the Missouri Botanical Garden 98: 205-239.

HIEPKO, P. 1990. Die Sammlungen des Botanischen Museums BerlinDahlem und ihre Geschichte. - In: Schnarrenberger, C. \& H. Scholz (eds.) Geschichte der Botanik in Berlin, Colloquium Verlag, Berlin: 297-318.

IGNATOVA, E.A., B.C. TAN, O.M. AFONINA \& M.S. IGNATOV. 2009 [2010]. Sematophyllum (Sematophyllaceae, Bryophyta), a new genus and family for Russia. - Arctoa 18: 213-216.

MERRILL, E. D. 1943. Destruction of the Berlin Herbarium. - Science 98 (2553): 490-491.

SAYRE, G. 1977. Authors of names of bryophytes and the present location of their herbaria. - Bryologist 80: 502-521.

SHAW, A.J. \& B. GOFINET. 2000. Bryophyte Biology. - Cambridge University Press, Cambridge, UK. Pp. 369-402.

THIERS, B. M. 1992. Indices to the species of mosses and lichens described by William Mitten. - Memoirs of the New York Botanica Garden 68: iv + 113 pages.

TSUBOTA, H., H. AKIYAMA, T. YAMAGUCHI \& H. DEGUCHI. 2001a. Molecular phylogeny of the Sematophyllaceae (Hypnales, Musci) based on chloroplast rbcL sequences. - Journal of the Hattori Botanical Laboratory 90: 221-240.

TSUBOTA, H., H. AKIYAMA, T. YAMAGUCHI \& H. DEGUCHI. 2001b. Molecular phylogeny of the genus Trismegistia and related genera (Sematophyllaceae, Musci) based on chloroplast $r b c$ L sequences. Hikobia 13: 529-549. 